\title{
Perception of Syahadatain Community to Social Cohesion as Capital to Realize Unity
}

\author{
Abdul Rohman \\ Faculty of Social Science and Political Science, Jenderal Soedirman University \\ Purwokerto, Central Java, Indonesia \\ E-mail : rohman_mudis@yahoo.com
}

\begin{abstract}
This study entitled : Perception Syahadatain Community on Social Cohesion as Capital to Realize Unity . The objective of this study are to determine Syahadatain community in building social cohesion and attempt to achieve unity in society.

Based on the study conducted, it could be concluded : 1 ) that the teaching of Islam has provided the basics of formation of social cohesion that is universal and leads to the values of truth ; 2 ) In building social cohesion in the community Syahadatain more influenced by their teachers ; and 3 ) In an effort to achieve unity with based on the construction of social cohesion, community Syahadatain easier and lighter. Becouse they have some teacher as the respected person.
\end{abstract}

Keywords-Perception; Syahadatain ; social cohesion;community

\section{BACKGROUND}

Indonesia is a country made up of diverse ethnic, cultural, and religious . Nation trip is quite long, from the fight against colonialism, the independence and the struggle for reforms that occurred in 1998. The tides turns. Now, in an atmosphere of post-reform era, Indonesia is still struggling to achieve progress in all fields, whether social, political, governmental, cultural and religious, in order to maintain national stability as one of the key staple in realizing the ideals of a prosperous society, prosperous and spiritually can be achieved. However, the dynamics of the emergence of certain groups, both political and religious trough continue coloring of this nation .

In the late development of religious denominations in Indonesia, particularly in the Muslim community is deeply felt , like a stream of Islam Jama'ah, Jama'ah Islamiyah, Ahmad Mushoddiq Group , Lia Aminudin Group, Ahmadiyah Group, the Islamic Defenders Front, Syahadatain, Gafatar, etc. This illustrates to describe that some groups to get sympathy and followed by most Muslims. It is as one of the effects of the opening of the freedom to appreciate the spiritual needs of the various religious dimension .

The growth of religious groups in the pasca reformation, their movement are radical and some persuasive - exclusive in its activities and teaching approach to get sympathy of adherents.
The Islamic Defenders Front ( FPI ) is a group of religious beliefs, which movement in performing commanding the good and forbidding abomination radically. Meanwhile, other groups such as Nahdlatul Ulama and Muhammadiyah, can be categorized as Islamic groups representing the movement groups through persuasive way . Then Islam Jama'ah groups and other minority groups, such as " Syahadatain " movement is dominated by persuasion - exclusive

In Islam there are three terms in religion, namely in terms of Muamalat ( social interaction ), ' Ubudiyyat ( Ritual ) and Ilahiyyat ( Theology ). In terms muamalat can not be separated from the imaging aspect of religion . Imaging religious groups arise regarding the worldview which underlies the understanding and religious attitudes, also in associated with the personality style of adherents society where personality will give to tolerance and moderation values. But in other respects, a personality that tends to limit themselves in their interaction will make which tend to limit themselves in their interactions will make the harsh attitudes and fanatical blind.

Normatively Islam is a mercy religion, uphold justice , humanity and equality . There are no barriers of cultural, social, and specially ideological separating social interaction. In the open social interaction will be to make faithful and religious community well . Islamic person is not disturbed, but they can worship in peace, and their faithful is also not disturbed others . Society will be harmonious with the attitude and life tolerant, peaceful and open to the neighbors, without prejudice and without suspicion. Even in building social cohesion, religious groups tends to be stronger in the holding rules which given by their teachers ( Drs. Ahmadi, spokesman Syahadatain Banyumas )

Islam is loves peace ( Q.S. 8:61 ), humanely ( Q.S. 17:70), independence in choosing a religion ( Q.S. $2: 256$ ), and realize the unity ( Q.S. 3 : 103 ). In the social interaction, the community encouraged to be able to sort the problem, that are profane humanity with theological matters of faith and the matters of sacred. All issues including social relations between human beings should not only be measured by the theological perspectives and the sacred dimension of monotheism alone . The Prophet declared: "that you are better understood in the 
affairs of your world" . This is that man was entrusted by God to organize and foster creativity in social reality according to the context of each matters. Social cohesion built of Syahadatain group is a social reality on the response of the circumstances surrounding community .

\section{FORMULATION ISSUE}

Based on the background of the problem, so there are three aspects of this study, namely:

a. How the base of social cohesion that was built by the Syahadatain community?

b. What are the factors affecting the Syahadatain community in building social cohesion?

c. How the perception of the Syahadatain community to social cohesion as capital to realize unity?

\section{SYAHADATAIN COMMUNITY AND SOCIAL COHESION}

\section{A. Social Cohesion}

The meaning cohesion actually departing from physics problems, which means: the gravitational pull between two (2) sections adjacent in the ingredients; or attractive forces between like molecules, derived from the electric force of the electric charge in the molecule or atom. While the attractive forces between the molecules of a type not referred to adhesion (Shadily, 1987). In public life, social cohesion can be defined as adhesion was built by a community based bond family, clan and genealogy in the frame ethnicity. In typological, social cohesion can be categorized into two types, namely intra-community, and social cohesion between communities. The historically of social cohesion intra community formed through a socio-cultural formation mechanism in a single community or single society, which in general occupies an area resident or several areas of habitation but maintained systems of etics and social order are the same, as the guide interact.

If social cohesion in intra community formed through social interaction mechanism driven by a sense of kinship , the social cohesion between communities formed more on the pragmatic economic mechanism. As for the theologically - cultural, social cohesion between communities derived from religious texts . At this level, social cohesion can actually be seen in two perspectives. First, social cohesion is an adhesive that is functionally an exact condensation or crystallization of the similarity of the family, clan, ethnic, similarity fate, occupation, cultural orientation, and social goals. Second, social cohesion is " major cause " for the formation of the community itself ( http : // www. Scribd.com/doc/4568418/Kohesi Social , downloaded, April 7, 2013 )

Related problems of social cohesion, Durkheim in Ritzer (2009) stated that the collective representation of society was made public, or at least through religious ritual. Therefore, religion is something that connects communities and individuals, because it is through ritual to which sacred, social categories became the basis for the concept of the individual. Then Giddens in Ritzer (2009) also state that the transformation of intimacy that continually leads to a movement toward " pure relationship " in order to survive, the social relations must be entered by each person of closeness continuously with the others; and which will continue to be maintained if the proximity was seen both sides can to give satisfaction enough to make them want to continue to survive in its. Giddens more emphasis on inner satisfaction factor when the relationships with others.

Then according to Alfred Schutz in Ritzer (2011), that human actions into a single social relationships when people give a certain meaning to his actions, and other human understand his actions as something meaningful. Subjectively understanding of the action is very important for the continuation of the process of social interaction. Understanding to social cohesion in the religious perspective is the manifestation of the belief in the truth of the religion itself. Every religion has a congregation who became his followers. Members of the congregation have considerable faith in the truth of religion that followed. What comes out of religion, either side of the faith, the holy book, way of worship, the all was believed to be the basic of life that brings happiness. That became a cornerstone of their guidelines for the whole community of the bond, and it is very strong to social cohesion.

Wach in Hendropuspito (1989), that the religion is a belief system, has a system of rules that binds his adherents or worship which has a system of rules that binds its adherents or worship and have a relationship system and social interactions. In this case the religion is not only viewed as a set of absolute rule that comes from God, but in view of the existing rules in the middle of the community. Therefore, every believer will have a strong cohesion of religion that followed. Religion becomes binding force for unity.

Wach opinion is in line with the opinion of Durkheim argued that religion becomes an essential factor for the identity and integration of society. Religion is a system of collective self-interpretation. For Malinowski, that "wholeness would happen if an area is strongly based on the life of the mutual benefits 'reciprocity' principles of legal" Then, according to Allport, that person feels included members of a group when he participates in activities and group behavior. For H.Carrier, there are four elements that can embody religious cohesion. They are the perception of the members about the state of their interdependent (interdependence); motivation; prestige group; and position in society. The expert opinion is strengthened by $\mathrm{J}$. Thibaut, after conducting research on the cohesion of the poorest groups, and he came to the conclusion that the group has a high status in the community has a strong cohesion, being a marginal religious groups have low cohesion on its members. However, if the group is marginal vengeful and hatred towards a high group, then the influence of a sense to protest and antipathy that make them establish a sense of unity better (Hendropuspito, 1989). 
Opinion Allport , H. Carrier , M. Deutsch and J.Thibaut, that cohesion are mutually reinforcing that religious groups were more influenced by the socio-cultural comparison to the influence of religion. Those opinions actually when it was confirmed by a group of Islamic religious currents, becoming weaker. It is as disclosed Abdul Rohman, et al (2008), that groups such as the Islamic Jama'ah which has now become the Indonesian Islamic Propagation Institute, or Ahmadiyya is a group that has a sense of stream is very strong group cohesion, they do not have to participate actively in the some activities or has a high prestige in their group.

\section{B . Syahadatain Community and Effort to Realize Unity}

The community in social and religious life is often identified with the group stream. While the group is a people gathered into a single unit. Then is meant by the group is a group whose existence stream in society are relatively smaller members than the other communities, especially in the Islamic religious community.

"Syahadatain" is a community that has a belief in the truth of Islamic teachings according to their interpretation. Therefore, this community has its own characteristics when compared with other Islamic groups, such as Nahdlatul Ulama and Muhammadiyah. The characteristic of them is not on the principle (aqidah) or in the conduct of worship, (eg. prayer), but more on the issue of worship branches namely in doing the wird (prase to God), tawassul (the relationship with God through prayer) and how to dress.

Syahadatain community are groups that live in the lives of other Muslims. In conducting worship, the Syhadatain group is " isolate " themselves. They do not conduct together with other groups of Islam. Model of worship is due to the belief, that the group believed that the teachings of the exercise as a truth. In the district of Banyumas denominational Syahadatain community followed by about 100 followers. This majority group in the District of Kembaran. This group has not spread as well as other Islamic religious groups.

In the building social cohesion Syahadatain group insists on the ideals of their teachers. Syahadatain community strongly adhere to the rules taught by Allah, the Prophet Muhammad SAW and their teachers. The teachings of Allah and His Messenger are represented in the form of instructions given by the teachers. Thus the position of the teachers being very central. Therefore the social cohesion that grows in the community Syahadatain not escape the influence of his teachers, either through lectures or through his behavior.

As the position of teachers in the Syahadatain community it is very central, so the effort to achieve unity in the life of society, the group also remains stressed and follow the instructions of their teachers. Thus efforts to achieve unity easier and lighter. This is caused by the influence of the strength of their teachers.

\section{IV.CONCLUSION}

Based on the above description can be concluded : a. Islamic teachings have provided the basics of formation of social cohesion that is universal and leads to truth values. The cornerstone is the basic for the group Syahadatain in building social cohesion.

b. Syahadatain community in building social cohesion is more influenced by the teachings and the exemplary their teachers.

c. Based on the capital of social cohesion, Syahadatain community easier to achieve unity in a diverse society.

\section{REFERENCE}

[1] Bachtiar, Harsya W., Agama Dan Perubahan Sosial Di Indonesia, dalam Bulletin "Dialog " Edisi No. 17, Jakarta, Badan Litbang Agama, 1984.

[2] Durkheim, Emile, 1947, The Elementary Form of The Religious Life, tranlated by Joseph Ward Swaim, Free Press, New York

[3] George Ritzer, Douglas J. Goodman, 2009, Teori Sosiologi, terjemahan, Kreasi Wacana, Yogyakarta.

[4] George Ritzer, 2011, Sosiologi Ilmu Berparadigma Ganda, Raja Grafindo Persada, Jakarta

[5] Hendro Puspito, 1984 O.C. dalam Sosiologi Agama, Kanisius, Malang.

[6] Johson, Doyle Paul, 1986, Teori Sosiologi Klasik Dan Moderen, penterjemah Robert M.Z., Lawang, Gramedia, Jakarta

[7] Shadily, Hassan ,1987, Ensiklopedi Indonesia, PT Ichtiar Baaru Van Hoeve, Jakarta, hal. 1806

[8] Wach, Joachim, Sociology Of Religio, The University Of Cichago Press, London, 1964.

[9] Internet:http://www. scribd.com/doc/4568418/Kohesi Sosial, (diunduh, 7 April 2013) 